CHILDREN OF FATE 



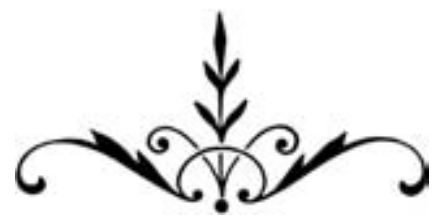

\title{
CHILDREN OF FATE
}

Childhood, Class, and the State in Chile, 1850-1930

\author{
Nara B. Milanich
}

Duke University Press Durham and London

2009 
(C) 2009 Duke University Press

All rights reserved

Printed in the United States of America on acid-free paper $\infty$

Designed by C. $\mathrm{H}$. Westmoreland

Typeset in Warnock with Whitman display

by Keystone Typesetting, Inc.

Library of Congress Cataloging-in-Publication Data

appear on the last printed page of this book. 
FOR MY PARENTS

FOR NICOLA, GIACOMO, AND LUCA 
